\title{
Evaluating the outcomes of four-year B. Ed program: A case study of Graduates of Public Sector University
}

\author{
Naila Siddiqua* \\ Nighat Parveen** \\ Muhammad Zakria Khan***
}

\begin{abstract}
The purpose of the study was to evaluate the outcomes of four year B. Ed program with respect to the objectives set by NACTE for teacher education program. It was a dire need of the society to produce competent and skilled teacher to build up a world class education system that are sincere and dedicated to their profession. NACTE has been developed as an autonomous body to ensure the quality of education. A descriptive case study was designed to collect data qualitatively through interview protocol. Questions were designed on the basis of subsidiary objectives related to international standard for teachers, modified and skillful curriculum and practicality of content through practicum. Data was collected from twenty passed out graduates selected by snow ball sampling technique and analyzed by thematic approach. Findings indicate that despite little weaknesses most of the objectives of NACTE and USAID program have been achieved. The participants expressed their views that after completing this four year B. Ed program they are able to know the use of different teaching strategies and skills which are required for an internationally licensed teacher. It was recommended that content courses should be revised to meet the new challenges and assistance should be taken from the concerned department to improve the concept of the student for related subjects.
\end{abstract}

Key words: NACTE, Teacher licensing, Practicum, Curriculum enrichment, Program Outcomes

* Assistant Professor, Department of Education, University of Karachi

** Teaching Assistant at Department of Education, University of Karachi

*** Social activist, promoting Education to underprivileged 


\section{Introduction}

Societies can be developed and reconstructed if the perception and planning made by professionals and philosophers is merged only with educational process. ${ }^{1} \mathrm{~A}$ teacher is the one who can incorporate these ideas and planning in the society by his effective way of teaching. The major difference in quality of school education is due to the variation in teacher effectiveness. ${ }^{2}$ That's why teachers can be acknowledged as a social reformer and planner who contributes his skills and services to build a nation. Research confirms that the most effective means to raise the quality of education across the developing countries is to improve the pedagogical skills. ${ }^{3}$

Despite the fact that $90 \%$ of the teachers serving in public sector schools are trained ${ }^{4}$ but their impact on student's performance and achievement is not visible. The education offered by public sector is not of good quality, students are prepared for rote learning, and are not encouraged to gain in-depth knowledge to improve their cognition level which helps them to establish their own judgment and enhance their ability to think critically. That's why it was the dire need to revitalize the present teacher education system by improving education quality and making it relevant to the present need. It is clearly understood that whatever policies are made, ultimately it would be implemented by teacher through teaching learning process.

The teachers should be prepared through advance pedagogical skills to face the issues and challenges of the modern education system and is capable to resolve them. Kafu ${ }^{5}$ describes teacher education is apparently developed and administered to produce school teacher to establish the system of education, and the theory behind this is that the teachers are made not born and teaching is an art through which teachers acquire not only knowledge but learn skills too. Hence reforms in teacher education are necessary. Harvey \& Green ${ }^{6}$ described importance of quality teacher;

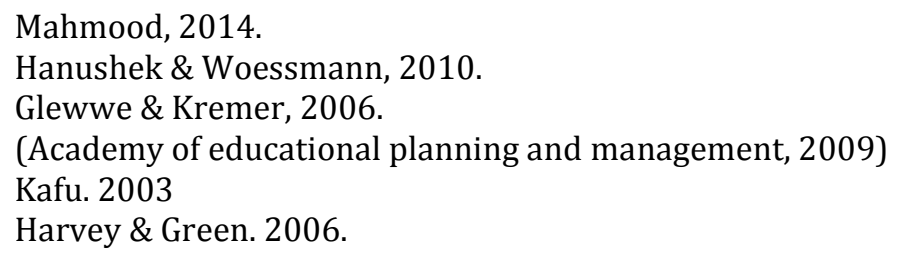


"The quality of nation depends upon the quality of its citizen. The quality of its citizens depends not exclusively, but on critical measures upon the quality of their education and, the quality of their education depends more than upon any single factor, upon the quality of their teacher."

Government of Pakistan has always been focusing in its all educational policies ${ }^{7}$ to improve the quality of teacher education and recently introduced a four year B. Ed (Hons.) and two years Associate Degree in Education (ADE) program and making it more effective and compatible to meet the international standard. Curriculum offered for this program by HEC (2010) pay attention to make teacher more competent in content area, and also in pedagogy to assure the students learning outcomes.

According to National education policy ${ }^{8}$, to improve the quality of education in Pakistan, standard of teacher education must be raised through reforms in pre-service training and standardization of professional qualifications. It figure out different issues with the quality of teacher education and suggested to replace the traditional teacher education with a more effective and comprehensive four-year post-K12 program ${ }^{9}$. Teacher education now becomes the responsibility of Higher Education Commission under the power given (in ordinance No. I, III, 2002) and the other services at the postsecondary level and it was an important implication of these policy reforms that affect positively on its development.

As in other discipline, to ensure and raise the quality of teacher education program accreditation is the most effective and widely used systematic process, in which a peer reviewed assessment based formal judgment made by an external body that the quality of a program or an institution meet the pre-determined standard and the graduate produced by these institutions are capable to enter in the teaching profession and have competence to become an effective teacher. It is continuous process in which a third party evaluate and develop a plan to ensures the quality and develop a plan to improve the standard.

\footnotetext{
Educational policies $(1947,1959,1979,1992,1998,2002$ and 2009)

Ibid 2009

Ministry of Education Government of Pakistan, 2009a.
} 
To ensure the quality of teacher education program in both public and private institution in Pakistan HEC assigned National Accreditation Council for Teacher Education (NACTE).

The new program has been initiated in different institution, funded by USAID Mission Pakistan (Pre-STEP/USAID, 2010) which was administered by Education Development Centre (EDC) in partnership with teachers college, Colombia University. The project assisted Pakistan's government to fortify basic education sector and improve the quality of pre-service teacher education. A two year ADE and four years B. Ed (Hons.) was introduced for both new and practicing teachers to upgrade their qualification. The Higher Education Commission (HEC), Provincial and Regional department of Education and teacher training institutes worked to implied the strategy across the country and supported by 21 Universities and 91 Government Colleges for elementary education to lift up the academic standard in teacher education program (USAID teacher education project-final report,2013). The project provides technical support to strengthen the system and to make sure the implement of standard-based teacher education program, which is helpful to produce knowledgeable, skilled and better-informed graduates from educational institutions to meet Pakistan's National Professional Standards for Teachers.

The project focus on three main objectives is as follows:

- Improved system and policies that support teachers, teacher's educators, and educational managers and education managers.

- Support HEC and ministry of Education (MoE) teacher's institutes to develop/revise, evaluate and finalize standards, curricula and modules for pre-service teacher education degrees.

- Develop a plan for implementing the new curricula for both new and existing teachers

Buchberger et al. ${ }^{10}$ discussed in their study that the main components and features of efficient teacher education program comprises on content knowledge, foundation courses, pedagogical courses, and teaching practices (Practicum) and it can be vary in their scope and ratio or percentage in different countries across the world.

${ }^{10}$ Buchberger et al.2000; UNESCO, 2000 


\section{Purpose}

The purpose of present study is to evaluate the outcomes of four year B. Ed program with respect to the designed objectives of NACTE in a public sector university.

\section{Objectives}

- To find out the outcomes of the four year B. Ed program.

- To analyze the objectives of NACTE regarding four year B. Ed program with respect to the outcomes.

- To investigate the perspective of passed out students regarding the success of four year B. Ed program with respect to the designed objectives.

- To measure the satisfaction level of teacher educators regarding four year B. Ed program

\section{Research Question}

- What are the outcomes of four year B. Ed program?

- What are the perspectives of the passed out students about the success of four year B. Ed program with respect to the designed objectives?

- To what extent the objectives of NACTE regarding four year B. Ed program are achieved?

- What is the role of this program to fulfill the needs of teacher educators?

\section{Review of Literature}

According to national council for teacher education, a program of education and research which is designed to train a person for teaching pre-primary to higher education level.

"All the formal and non-formal activities and that help to qualify a person to assume responsibilities of a member of the educational profession or to discharge his responsibilities more effectively"11.

11 (Goods Dictionary of Education) 
Teacher education is a program to develop and strengthen the teacher to face the challenges and fulfill the standard of their profession according to modern needs ${ }^{12}$.

In past it was thought that teachers were trained like technicians and mechanics through teacher training program which had focused only training of skills and had a limited and narrower scope and the goals and objectives of the training are very constrictive ${ }^{13}$.

A program for the training of pre-service and in-service teacher which enable the student teacher to enhance their knowledge and pedagogical skills and enable them to acquire competence to apply these skills in their classroom practices ${ }^{14}$.

Chauhan. A and Sharma. $\mathrm{P}^{15}$ had summarized the above discussion in their study as; Teacher education encompasses teaching skills, sound pedagogical theory and professional skills. Teacher Education $=$ Teaching Skills + Pedagogical theory + Professional skills.

Many studies show that teaching is an art and a science, and teachers not only get knowledge but they must know about teaching skills which is known as "tricks of trade". The theory behind teacher education is "teachers are made not born" instead of the assumption that teachers are born, not made.

To apply the theory of making teachers, training of different strategies, techniques and approaches would be provide them which facilitate the teachers to plan and convey their knowledge in a better and appropriate manner which also include proper reinforcement and effective assessment, class room management skills and better communication skills. Professional skills like soft skills, computer skills, management skills, counseling skills, interpersonal and information retrieving skills and the most important is lifelong learning skills also assist teachers to upraise in their profession and move forward to nurture and nourish their profession.

\footnotetext{
Ongachi W.M, Okello,O.M, James.A, 2013.

Biswas.P,2012.

Namunga.N.W \& Otunga.R.N, 2012.

Chauhan. A and Sharma. P
} 
These views summarize the importance and the role of teacher education for the social development of society and in this respect education is regarded as the driving force for social development ${ }^{16}$.

\section{Teacher Education in Pakistan}

Teacher education plays a pivotal role to build and regenerate the education system of a society. In Pakistan, Government Colleges for Elementary Teachers (GCETs), College for Education (GCE) and University Department of Education are major institutions that contribute teacher training through different program. Presently more than three hundred teacher education institutes or Training Centre are serving in different public and private sector offering different teacher education program from primary school certificate to $\mathrm{Ph}$. D in Education ${ }^{17}$ but the quality of teachers is not satisfactory, Education policy ${ }^{18}$ stated that "poor quality of teacher in the system in large number is owed to the mutation [forms] in governance, an obsolete preservice training structure and ales than adequate training regime"19. The policy observed that due to the bad governance a complete overhaul is necessary. The USAID also points out that in Pakistan only 8 out of 100 students passed their secondary school due to the incompetent teachers and poor quality education in public sector.

Today's world is continuously growing, dynamic and ever-evolving, and teacher education has to keep up the modern need and trends to train teacher according to these ever changing world who can face the challenges of this ever changing society. Over the last two decades the demand in quality in teaching drastically increased which has changed the teacher education ${ }^{20}$. Like other advance countries, a quick change in teacher education has also observed in Pakistan from last decade due to increasing global needs and critical views reported by UNESCO in relation to the teacher training in Pakistan, which points out that, "absence of quality must be tackled urgently in a context where teacher-learner connection are mediated by the supportive management, as nicely as through an empowering policy environment ${ }^{21 "}$.

\footnotetext{
(David Melita Ole Katitia, 2015).

MoE, USAID \& UNESCO, 2009.

Education policy 2009

Government of Pakistan, NEP 2009,p.42

Furlong, 2008.

UNESCO, 2008.
} 
The National Education Policy 1998-2010 showed concern regarding teacher education quality by observing, "The qualitative dimension of teacher education program has received a marginal attention resulting in mass production of teachers with shallow understanding of both the content and methodology of education 22 ". As a result quality in teacher education and teacher professionalization has become the main motive within Pakistan. Therefore quality teaching and professionalization mechanism has become a common theme and essential component of government policies.

To fulfill the need of $21^{\text {st }}$ century USAID has launched the Teacher education Project to support the Higher Education Commission and Government of Pakistan to meliorate the quality of teaching and learning practices at primary and secondary level for a longer period. The project supports the government of Pakistan through the Provincial Department of Education. A four year professional degree program - the B. Ed (Honors) for teachers has been implemented by the Higher Education Commission which played the role of host institution ${ }^{23} .9$ and 18-months pre-service preparation program has been started to phase out from across the country and it is great success for Pakistan to establish and develop a new teacher education system. It is a tremendous beginning toward a bright future for teacher education in Pakistan to compete the $21^{\text {st }}$ century demand.

\section{Role of Nacte}

Accreditation is a standard practice in many professions in Pakistan. But, till recent no measures had been undertaken to raise and ensure the quality of teacher. Neither were there any standards for teachers, nor was there any system to ensure quality of Teacher Education Programs. NACTE was established in 2007 to ensure quality of Teacher Education Programs and the teacher. NACTE, under the power given in the Ordinance 2002, the HEC have constituted various councils to ensure the quality of education in their respective disciplines. It established the National Accreditation Council for Teacher Education as an autonomous body through a Federal Government notification in the Gazette of Pakistan, Extra August 30, 2007 for ensuring the quality of Teacher Education Programs in public and private institutions in Pakistan ${ }^{24}$.

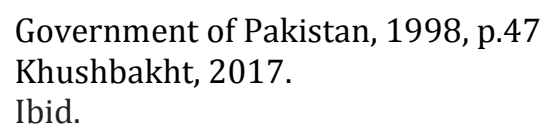


The NACTE has representation of Ministry of Education, Planning Commission, Higher Education Commission, Provincial / Areas Departments of Education, public and private sectors universities offering Teacher Education Programs and experts in the field of Teacher Education ${ }^{25}$.

\section{Nacte's Scope and Mission}

NACTE's mission is to ensure the conduct of high quality Teacher Education Programs as an integral part of higher education through a sustained professional internal Evaluation and External Academic Audit. Its mandate includes Teacher Education Programs offered by institutions of higher learning in any of the following categories:

- Institutions chartered by the Federal Government or Provisional Government in the relevant field.

- Institutions affiliated by the chartered universities or degree awarding institutions through the respective universities/institutes.

- Institutions offering degree programs under affiliation/collaboration with foreign universities under the approval of HEC.

- When a multi-campus institution presents a program for accreditation, each campus will be considered as separate institutions (NACTE, Accreditation for Quality Assurance in Teacher Education).

\section{Nacte's Vision}

- Assessment of Teacher Education Programs in a systematic and recurrent manner.

- Award accreditation levels based on objective, valid and transparent procedures.

- Provision of assessment based concrete suggestions for improvement of programs.

- Help and support institutions for self-assessment ${ }^{26}$.

\section{Nacte's Progress}

NACTE, in spite of a number of constraints and challenges, has made a tremendous progress on developing the teacher accreditation system on systematic, and scientific base adopting consultative and participatory approaches engaging nationwide partners and stakeholders of Teacher

NACTE, NACTE News Letter, 2011

Ibid. 2009 
Education; created awareness about the need and benefits of accreditation and developed the initial professional mass to undertake the accreditation tasks at the institutional and NACTE levels. Many of the activities materialized with the financial and technical support of USAID and UNESCO. NACTE has:

- Developed the National Standards for Accreditation of Teacher Education Programs (NSATEP).

- Developed the Process and Procedures of Accreditation including detailed manuals and documents for all concerned e.g., institutions evaluators.

- Created awareness about accreditation of Teacher Education Program by conducting two international conferences, and number of national and provincial level seminars.

- Trained initial professional mass for accreditation of at least 45 external evaluators.

- Trained the staff of 30 candidate institutions for accreditation.

- Launched electronic and print mode of dissemination and outreach such as the website www.nacte.org.pk, Biannual Newsletter, and Printed Materials of different types.

- Attained membership of international quality assurance agency, Asia Pacific Quality Network (APQN) (NACTE, Accreditation for Quality Assurance in Teacher Education)

\section{Method and Material}

The present study is descriptive in nature following the qualitative paradigm of research. Passed out Students of four year B. Ed program of a renowned Public Sector University comprised of the population in which twenty students were selected by snow ball sampling technique. Participants' views and perspective regarding the objectives were explored through structured interview and evaluated the outcomes of program. The tool was comprised of eight questions based on the three main with subsidiary objectives designed by USAID for four year B. Ed program. Data was analyzed by thematic approach.

\section{Findings}

- After completing this program teachers are more competent and equipped with advanced pedagogical skills. It is a great addition in county's human resources to improve the quality of education in Pakistan. 
- Passed out students are satisfied about the success of this program, but somehow they have some reservation regarding content courses and implication of practicum in practical.

- Most of the objectives of NACTE are achieved but still there are some gaps which are needed to be filled to achieve the designed objective.

- Despite minor differences in content and practical implication of practicum this program seems to coincide with international standard and very much successful to fulfill the needs of the teacher education.

- There is lack of synchronization between class room instruction and practicum. There are administrative issues in organization of practicum.

\section{Discussion}

The respondents enthusiastically shared feelings regarding their expectation before joining this program, some of the responses are that they want to become a professional teacher who is fully equipped with all the pedagogical skills. Few of them answered to improve the education system after becoming a trained teacher. Others wanted to contribute to improve the quality of education in Pakistan.

In response of the question about the fulfillment of their expectation, few of them were satisfied. Some of them answered that there are some deficiencies in content and subject matter, while the rest of them were somehow satisfied, but still have some reservation as well.

When answering the synchronization between class room instruction and practicum only few of them replied in positive and stated that practicum is the practical of that entire study which have learnt in class room instruction. Rest of them responded dissatisfactory and showed concern in coherence between class room instruction and practicum. One of the respondent said that class room instruction are taught in an ideal condition but when they practically implemented the outcomes are totally different.

When they were asked about the differences about one year B. Ed program and four year B. Ed program, most of them agreed that with the four year B. Ed program they got more in depth content knowledge and a sufficient time for practicum comprising of two semesters. According to one respondent, "obviously it is very different, apart from duration we have more opportunities to learn and enhance our professional skills." 
In the response of comparison the national B. Ed program with the international B. Ed program most of them rated 8 out of 10 and added since this program is designed and offered by international agency, therefore, definitely meet the international standards of teacher education. Two of the respondents showed their concern that although this program is designed with international standard but with respect to local perspective there is a need of amendment.

While answering the achievement of objectives majority of the respondent said that despite of some weakness this program is very much successful to achieve the designed objectives. A respondent answered that, "...not 100\% but we can say that we have achieved most of the objectives and our teachers are now equipped with professional skills of international standards." A small number of participants expressed that although the content is successful but due to weak teaching some objectives are not achieved.

In response of the question, how they rate their skills with the skills required for a licensed teacher? Majority rated themselves between 7 to 8 out of 10 and said that now they think that they have the required skills of a licensed teacher but few of them responded very honestly that they don't know about the licensed teacher.

Most of the respondents rated 8 out of 10 while giving the answer of the role of this program to fulfill the teachers' need, and stated that this program is very much successful to fulfill teachers' need. They further added that "it is a perfect combination of academic learning and practical implementation and a great opportunity for those who want to become a trained teacher with international standard." Only 3 of them argued that there are some gaps which are needed to be filled to fulfill teachers' need.

\section{Conclusion}

The present study is an attempt to evaluate the outcomes of four year B. Ed program. It was a case-study conducted in a renowned public sector University. It may be concluded that the designed objectives of the program have been achieved successfully to a certain extent. Practicum has been identified to pay more attention for much better results. Practicum is a significant component of this 4-year B. Ed program with 9 credit hours, requires more careful planning and implementation. Content courses are the 
major source of subject matter knowledge also required to revise and deliver effectively.

\section{RECOMMENDATION}

- Although this program is very successful to train the teachers but there are recommendations to make it more improved and advanced to meet the international standard.

- To fill the gaps authorities should refine and periodically revise the standard of NACTE.

- Implementation is needed along with the theoretical knowledge to produce harmony in class room instruction and practicum to meet the international standard.

- Content courses should be improved since it does not meet the international standard and teachers have faced difficulties while practicing it in classroom.

- NACTE and USAID required to enhance and modify their objectives with respect to the change in nature of world of work. 


\section{References}

Ahmed, M.-E.-R. "Factors Affecting Initial Teacher Education in Pakistan: Historical Analysis of Policy Network." International Journal of Humanities and Social Science 2, no. 13 (2012): 104-113.

Akbar, Rafaqat Ali. "Beliefs and Practices of Teacher Educators Teaching B.Ed (Hons) and ADE in Universities and Affiliated Colleges in Punjab." Bulletin of Education and Research Bulletin of Education and Research 35, no. 2 (2013): 91-106.

Ankit Chauhan, P. S. "Teacher Education And Total Quality Management." The International Journal of Indian Psychology 2, no. 2 (2015).

Bengali, K. History of Educational Policy Making and Planning in Pakistan. Islamabad: Pakistan: Sustainable Development Policy Institute (SDPI), 1999.

Biswas, P. "Teacher Education In India." ABHINAV National Monthly Refreed Journal Of Research In Arts \& Education 2, no. 9 (2012).

Cochran-Smith, M. "Studying Teacher Education: What We Know And We Need To Know." Journal of Teacher Education 56, no. 4 (2006): 301-306.

Darling-Hammond, L. "Assessing Teacher Education: The Usefulness of Multiple Measures for Assessing Program Outcomes." Journal of Teacher Education 57, no. 2 (2006): 120-138.

Dilshad, M. H. "Quality Indicators in Teacher Education Programmes." Pakistan Journal of Social Sciences 30, no. 2 (2010): 401-411. 
Farhat Khanam, S. A. "Teaching Practice in B. Ed: Prospective Teachers' Perception of Theory and Practice." NICE Research Journal, 2017: 19-29.

Fred Korthagena, J. "Developing Fundamental Principles For Teacher Education Programs And Practices." Teaching and Teacher Education, 2006: 1020-1041.

Hina, K. The USAID Pre-Service Teacher Education Program and Teacher Professionalization in Pakistan. Newcastle Upon Tyne,UK: Cambridge Scholars Publishing, 2017.

Lal, D. "A Journy of Teacher Education." International Journal of Peace, Education and Development 4, no. 1 (2016): 9-17.

Mahmood, K. "The Silent Revolution: Rethinking Teacher Education In Pakistan." Journal of Research And Reflection In Education 8, no. 2 (2014): 146-161.

Mirza, Munawar S. "Accredetation standards and procedure for quality assurance in Teacher Education." http://www.nacte.org.pk. n.d. http://www.nacte.org.pk/Download/Accreditation_Standards_Procedures.p df.

National Accreditation Coucil for Teacher Education (NACTE). Annual Report, Pakistan: NACTE, 2015-2016.

Nick W. Namunga, R. N. "Teacher Education As A Driver For Sustainable Development In Kenya." International Journal Of Humanities And Social Science 2, no. 5 (2012). 
Jhss, Vol. 7, No. 1, January to June, 2016

Shakeel Hussain, A. N. "Impact of Usaid Teacher Education Project on the Development of Teacher Education at Elementary Level." Gomal University Journal of Research, 2016: 83-89. 